\title{
EFFECT OF MICROBACTERIUM BARKERI ON THE RELEASE OF WATER- SOLUBLE FORMS OF PHOSPHORUS IN COMPOST BASED ON SEWERAGE SEDIMENT
}

\author{
Krutyakova ${ }^{l} V$., Pilyak ${ }^{l} N$., Dishliuk ${ }^{2} V$. , Nikipelova ${ }^{l} O$. \\ ${ }^{I}$ Engineering and Technological Institute "Biotechnica" NAASU, Ukraine \\ e-mail: biotechnical.od@gmail.com \\ ${ }^{2}$ National Scientific Center "Institute for Soil Science and Agrochemistry Research named \\ after O.N. Sokolovsky", Kharkiv, Ukraine \\ e-mail: dyshlyuk_ve@ukr.net
}

\begin{abstract}
In the conditions of laboratory model experiment on composting of sewage sludge the influence of active phosphate-mobilizing bacteria on the release of water-soluble forms of phosphorus was studied. The experimental scheme included known active phosphate-mobilizing bacteria isolated from various ecological niches. The following components were used for composting: sewage sludge (SS), winter wheat straw and a suspension of phosphate-mobilizing microorganisms isolated from SSs of municipal treatment plants. The largest increase in water-soluble forms of phosphorus at the final stage of composting due to the introduction of Microbacterium barkeri. The greatest growth of water-soluble forms of phosphorus at the final stage of composting is provided by
\end{abstract}


the introduction of Microbacterium barkeri LP-1, which can be explained by the greater adaptation of this strain to the substrate used in the experiments.

Key words: sewage sludge, composts, winter wheat straw, suspension of phosphatemobilizing microorganisms, water-soluble forms of phosphorus

\section{Introduction}

In terms of nitrogen and phosphorus, sewage sludge (SS) is equivalent to (or exceeds) manure litter, but the availability of these biophilic elements in them for plants is low (the content of mobile forms of NPK in dried sewage sludge (SS) is 7-10\% of their total number). At the same time, the organic matter of SSs is an available energy material for microbiota development, so it is advisable to find safe ways to increase the availability of phosphorus compounds in SSs for plants using their bioconversion and removal of reactive microorganisms, which will enhance phosphorus mobilization from hard-to-reach compounds.

It is known about a significant number of phosphate-mobilizing bacteria isolated from the rhizosphere soil of cultivated plants, which are able to dissolve sparingly soluble mineral and organic phosphates of the soil, as a result of which plants receive additional phosphorus nutrition from soil reserves.

Later, the technology of biocomposting of cattle manure was developed using the bacterial strain Pseudomonas Putida (Ps. Putida) and phosphorites in order to obtain raw materials enriched with mobile forms of phosphates. But due to the destruction of the livestock industry, it is advisable to search for new types of local fertilizer resources and develop effective methods to increase the availability of phosphorus compounds.

One of the promising areas of use of SSs - bioconversion of organic waste - obtaining available organic raw materials (compost) with the participation of phosphate-mobilizing microorganisms. To increase the carbon content in the compost mass during composting SSs use special additives - fillers [26].

Phosphorus is an important element of plant nutrition, promotes their growth and development. Lack of phosphorus in the soil delays the growth and development of plants, reduces the efficiency of photosynthesis and the ability of perennial legumes to fix molecular nitrogen from the atmosphere. It is known [27] that the concentration of available phosphorus in the soil is always low due to the continuous process of its absorption by plants. Sufficient reserves of phosphorus in the soil for the formation of crops can be replenished, mainly through the introduction of mineral and organic fertilizers, the use of microbial drugs.

The low availability of natural soil phosphorus for plant growth acts as a limiting factor for increasing crop yields. Because phosphorus undergoes precipitation and sorption reactions on soil colloids, much of the introduced and natural soil phosphorus is unavailable. However, inorganic phosphorus fertilizers are expensive. In addition, when the available natural resources of phosphorus are rapidly declining, it is impractical to rely solely on inorganic phosphorus fertilizers.

Ensuring a normal level of phosphorus nutrition is one of the main conditions for the formation of high crop yields. The soil microbiota is actively involved in the mobilization of sparingly soluble phosphates, has a positive effect on plants, improving their phosphorus nutrition, growth, development and productivity. Therefore, phosphate-mobilizing microorganisms can become one of the components of bioorganic fertilizers.

The purpose of this work is to obtain an active phosphate-mobilizing bacterial strain that is able to show high activity in the mobilization of phosphorus from hard-to-reach compounds in easily accessible when composting sewage sludge from urban treatment plants. 


\section{Materials and methods}

For the first time, phosphate-mobilizing microorganisms, the products of the metabolism of which are the ability to dissolve sparingly soluble mineral and organic forms of phosphorus, were isolated from the sewage sludge of the biological treatment plants "Southern" (SS) and "Northern" (NS) in Odessa. Non-pathogenic strain of bacteria Microbacterium barkeri LP-1 is deposited in the Depository of the Institute of Microbiology and Virology. D.K. Zabolotny National Academy of Sciences of Ukraine. Its registration number in the Depository is IIR B-7691. The conclusion on the study of the virulence of the strain Microbacterium barkeri LP-1 in a model of white mice. The strain is maintained in viable condition in the collection of the Engineering and Technological Institute "Biotechnology" NAAS. Thus, the bacterial strain Microbacterium barkeri LP-1 has undergone hygienic regulation according to the procedure: it is safe for humans, warmblooded animals and beneficial fauna, non-phytotoxic.

The taxonomic status of Microbacterium barkeri was established by determining the fatty acid composition of the total lipids of the strain. To identify it, we used MIDI shertock 4.5 software and the library of fatty acid profiles of aerobic microorganisms RSTBA in version 6.2.

Isolation of phosphate-mobilizing microorganisms and their number were determined on nutrient agar medium Muromtsev by serial dilutions [10]. The activity of bacteria before the mobilization of organo- and mineralphosphates was determined by the method of Erdea [11].

The content of total phosphorus in composts was determined by [12], water-soluble phosphorus - by [13].

In the conditions of laboratory model experiment on composting of sewage sludge the influence of active phosphate-mobilizing bacteria on the release of water-soluble forms of phosphorus was studied. The experimental scheme included known active phosphatemobilizing bacteria isolated from various ecological niches (Enterobacter nimipressuralis (Ent. nim.), Pseudomonas putida (Ps. putida)). The following components were used for composting: sewage sludge (SS), winter wheat straw and a suspension of phosphatemobilizing microorganisms isolated from SSs of municipal treatment plants.

\section{Results and discussion}

According to the results of the research, data were obtained on the release of inaccessible forms of phosphorus into those available during composting of wastewater sludge.

According to the obtained results (Table), the greatest growth of water-soluble forms of phosphorus at the final stage of composting is provided due to the introduction of Microbacterium barkeri pcs. $L P-1$, which can be explained by the greater adaptability of this strain to the substrate that was used in the experiments. Bacterial strains that are isolated from other ecological niches are actively developing in those ecological niches from which they were isolated. Their development in sewage sludge may be limited by a number of factors. That is why Microbacterium barkeri pcs. LP-1 provides more release of water-soluble forms of phosphorus at the final stage of composting. 
Table. The content of water-soluble forms of phosphorus in compost based on sewage sludge depending on the introduced microorganism (final stage of composting)

\begin{tabular}{|c|c|c|c|}
\hline $\begin{array}{c}\text { Variants of the } \\
\text { experiment }\end{array}$ & $\begin{array}{c}\text { Experimental options } \\
\text { General phosphorus, } \\
\mathrm{mg} / \mathrm{kg}\end{array}$ & $\begin{array}{c}\text { Mineral } \\
\text { phosphorus, } \\
\mathrm{mg} / \mathrm{kg}\end{array}$ & $\begin{array}{c}\text { Water-soluble } \\
\text { phosphorus, } \\
\mathrm{mg} / \mathrm{kg}\end{array}$ \\
\hline $\begin{array}{c}\text { ERUs with SBU } \\
\text { "Southern" }\end{array}$ & 9700,0 & 8770,0 & 100,0 \\
\hline ERUs with SBU "North" & 23400,0 & 23020,0 & 130,0 \\
\hline PDS compost + straw & 29400,0 & 25970,0 & 300,0 \\
\hline PNS compost + straw & 29700,0 & 25490,0 & 280,0 \\
\hline $\begin{array}{c}\text { PDS compost }+ \text { straw }+ \\
\text { Ent. } \text { nim. }\end{array}$ & 8700,0 & 6100,0 & 120,0 \\
\hline $\begin{array}{c}\text { PDS compost }+ \text { straw }+ \\
M . \text { } \text {. }\end{array}$ & 28100,0 & 25630,0 & 420,0 \\
\hline $\begin{array}{c}\text { Compost PDS }+ \text { straw }+ \\
\text { Ps. } \text { Putida }\end{array}$ & 9100,0 & 8360,0 & 110,0 \\
\hline $\begin{array}{c}\text { PNS compost }+ \text { straw }+ \\
\text { M. } b .\end{array}$ & 27900,0 & 25500,0 & 440,0 \\
\hline $\begin{array}{c}\text { PNS compost }+ \text { straw }+ \\
\text { Ps. } \text { Putida }\end{array}$ & 8800,0 & 7910,0 & 120,0 \\
\hline $\begin{array}{c}\text { PNS compost }+ \text { straw }+ \\
\text { Ent. } \text { nim. }\end{array}$ & 9000,0 & 8170,0 & 120,0 \\
\hline
\end{tabular}

\section{Conclusions}

Thus, the bacterial strain Microbacterium barkeri, which was isolated from the sewage sludge of Odessa, is able to show high activity in the mobilization of phosphorus from hardto-reach compounds in easily accessible when composting sewage sludge from urban treatment plants.

\section{Bibliography}

1. Токмакова Л.М., Трепач А.О., Шевченко Л.А. Ефективність фосфорного живлення рослин кукурудзи за дії Поліміксобактерину. Вісник Полтавської державної аграрної академії. 2019. № 1. С. 73-80.

2. Михновская А.Д. Микробиологическая характеристика черноземов Украины и ее применение под влиянием обработки и удобрений. Бюл. ВНИИСХМ. 1986. № 44. C. 12-24.

3. Braunova O., Bernat Y. Utilization of phosphorus from $\mathrm{Ca}_{3}\left(\mathrm{PO}_{4}\right)_{2}$ by soil micromycetes. Acta fac. rerum natur. Univ. comen. Microbiol. 1980 (1981). No 8-9. P. 129-142.

4. Городній М. М. Проблеми використання осадів стічних вод для виробництва добрив. Вісник аграрної науки. 2013, вересень. С. 77-82.

5. Regulation of phosphorus uptake and utilization: transtioning from current knowledge to practical strategies / Md. Mahmudul Hasan, Md. Mainul Hasan, Jaime A. et al. Cellular and Molecular Biology Letters. 2016, 21. P. 1-9.

6. Носко Б.С. Сучасні проблеми фосфору в землеробстві і шляхи їх розв'язання. Вісник аграрної науки. 2017, № 6. С. 5-12.

7. Гаценко М.В., Луценко Н.В., Волкогон В.В. Роль фосфатмобілізувальних мікроорганізмів в оптимізації вермикомпостування органіки, збагаченої фосфоритами. 
Основи формування продуктивності сільськогосподарських культур за інтенсивних технологій вирощування: Зб. наук. праць Уманського держ. університету. Київ, 2008.

C. 229-235.

8. Гаценко М.В., Волкогон В.В. Оптимізація вермикомпостування органіки, збагаченої фосфоритами, за участі фосфатмобілізувальних мікроорганізмів. Мікробіологічний журнал. 2010. № 3. С. 14-19.

9. Гаценко М.В., Волкогон В.В., Токмакова Л.М., Луценко Н.В. Мікробіологічні аспекти біокомпостування гною ВРХ з фосфоритами за участю фосфатмобілізувальних бактерій. Сільськогосподарська мікробіологія. 2010. № 11. С. 75-89.

10. Теппер Е.3., Шильникова В.К., Переверзева Г.И. Практикум по микробиологии. М.: Колос, 1979. 215.

11. Erdey L., Fleps V., Bodor E. Colorimetric determination small quantity phosphates. Acta chimica academiae scientiarum Hungariceae. 1954. Vol. 5. № 1. Р. 65-80.

12. ДСТУ 4290:2004 Качество почвы. Методы определения валового фосфора и валового калия в модификации ННЦ ИПА им. А. Н. Соколовского.

13. ДСТУ 4115-2002 Почвы. Определение подвижных соединений фосфора и калия по модифицированному методу Чирикова. 